\title{
AN EVALUATION OF THE IMPACT OF A LIFE SKILLS PROGRAMME IN THE WORKPLACE
}

\section{FM Taute}

\section{INTRODUCTION}

Tschohl (2004:24) states that too much emphasis is placed on increasing knowledge (which is important), but that companies can get far better returns on training investments by putting more focus on people skills. Tschohl added that competence building through Life Skills education may be the single most effective preventative strategy for dealing with social issues and concerns in most communities.

Life Skills can be defined not only as the skills but also the insight, awareness, knowledge, values, attitudes and qualities that are necessary to empower individuals and their communities to cope and engage successfully with life and its challenges in South African society (Bender \& Lombard, 2004:87). In Life Skills training the focus will thus be on the employee in his or her totality.

\section{THE NECESSITY OF LIFE SKILLS TRAINING}

The importance of Life Skills acquisition should not be under-valued. Life Skills acquisition can and should go on throughout a person's lifelong learning experiences - in formal, non-formal and informal settings (Roup, 1994; Bender \& Lombard, 2004). Life Skills acquisition should thus become an integral part of any training programme and should be endorsed as part of the process of lifelong learning towards self-actualisation.

TABLE 1

BENEFITS OF LIFE SKILLS ACQUISITION (Roup, 1994:1-4)

\begin{tabular}{|l|l|}
\hline \multicolumn{1}{|c|}{ TO THE INDIVIDUAL } & \multicolumn{1}{c|}{ TO THE EMPLOYER } \\
\hline empowerment and self-actualisation & optimises the performance of the workforce \\
\hline better sense of pride/self/dignity & employees are trained beyond their "production roles" \\
\hline ability to plan and think ahead & workers will work better with others \\
\hline more life satisfaction & better communication \\
\hline greater individual stability & less frustration \\
\hline more comfortable with life & better problem solving \\
\hline a better home life & more creative thinking \\
\hline able to deal with children effectively & more commitment to the job \\
\hline $\begin{array}{l}\text { command respect from friends and } \\
\text { family }\end{array}$ & more job satisfaction \\
\hline improved self-confidence & people are more responsive \\
\hline
\end{tabular}

The demands of modern life are extremely strenuous. To meet these demands and attain success in life, it is important to possess the necessary knowledge and skills. Research by Taute (1992) proved that the social functioning of people is hampered by too much frustration, too little satisfaction and insufficient contentment with life which can lead to companies having a high sick leave record and staff turnover. It is therefore essential that an employee with ideals, who wishes 
to deliver service of a high standard, should be willing to remain a student. Continuous study enables the employee to achieve constant professional development, to utilise his/her potential to the full and to take the best advantage of the opportunities available to him/her.

While the importance of formal training can never be emphasised enough, it is nevertheless equally important to note that there are other aspects of the total functioning of a person which are not necessarily addressed by formal training - the growth of interpersonal skills and the pursuit of a healthy lifestyle. "Developing your interpersonal skills is not only beneficial in helping you satisfy the demands of the employer. It can also greatly reduce work stress, increase your productivity and ultimately enhance your reputation, perhaps your position within the firm" (Messmer, 2001:28).

By being exposed to a Life Skills programme, an employee has the opportunity to invest in him/herself, learn to handle frustration, enhance satisfaction regardless of circumstances, and experience increased contentment with life. If one takes the opportunity to enrich oneself through a Life Skills programme, productivity may increase, and others such as family, colleagues and employers may also benefit from the programme. Training in Life Skills enables employees to utilise their newly acquired knowledge and skills to make responsible choices and to enhance their well-being and social functioning throughout their lives. This means that training and development are central to Life Skills.

Nelson-Jones (1993:10) stated that Life Skills entail a range of attitudes, knowledge and skills that enable people to deal effectively with the demands and challenges of everyday life. Carrell, Elbert and Hatfield (1995:399) asserted that employee education is used to describe basic skills training programmes, whereas general training programmes focus on training in which employees gain skills that can be utilised at most workplaces. Maree and Ebersohn (2002:82) state that Life Skills education is designed to facilitate and reinforce psycho-social skills, thus contributing to the development of employees and the prevention of health and social problems.

Sloan, Gruman and Allergrante (1987) claimed that Life Skills training enables employees to become critical consumers of choices and that Life Skills facilitate change that can be sustained. The author believes that employees learn and apply new skills for living that make them productive. Not only must employees have a sound mind, but they must also have a "sound body".

Magney (1996:564) asserted that, with the growing emphasis on teamwork within organisations, Life Skills play a vital role in enhancing team or group work through developing the relevant social skills. Teamwork is not just a sporting metaphor, but also a fact of everyday working life. Growing use of teamwork is part of an on-going re-organisation of workplace relations. Life Skills can thus play a vital role in addressing problems encountered through teamwork.

\section{PURPOSE OF THE LIFE SKILLS PROGRAMME}

The purpose of this Life Skills programme was to assist employees through experiential opportunities to increase their knowledge, and to improve their skills in, amongst other things, the identification and management of stress, the formulation of goals, motivation, dealing with conflict, communication with themselves and others, self-assertiveness and the improvement of self-image, effectiveness and success. All these are important aspects that contribute to the makeup of a leader. If employees' knowledge and skills can be enhanced through a Life Skills programme, one can succeed in changing their attitudes within the workplace.

Various factors, listed below, motivated this research. 
- Life Skills programmes are presented without evaluation of their impact.

- The author has been asked to present this Life Skills programme to the staff of a tertiary institution. This opportunity allows for evaluation of the programme. (For ethical reasons the tertiary institution's name will not be revealed).

- This programme was developed and tested during 1992, and since revised and updated on numerous occasions. The author was curious to determine whether it could still succeed in the changed environment and circumstances.

The main goal of this study was to evaluate the impact of a Life Skills programme on the personal growth, skills and enhancement of social functioning of the employees of the tertiary institution. Potgieter (2005:117) referred to social functioning as the way people interact with their physical and social environment, and with the people and social institutions with which they are in contact.

\section{RESEARCH PROBLEM}

The main research problem was to determine the impact of a Life Skills programme on the social functioning of adults. A second problem that stemmed from the primary problem was ascertaining the effectiveness of the Life Skills programme in contributing to:

- the knowledge, skills and attitude of adults towards control, success, self-communication, lifestyle, responsibility and self-image (personal); and

- the knowledge, skills and attitude towards stress management, communication skills, conflict management and self-assertive behaviour (interpersonal).

\section{RESEARCH HYPOTHESIS}

The research hypothesis is: the Life Skills programme can effectuate a difference in knowledge, skills and attitudes of adults.

\section{THE LIFE SKILLS PROGRAMME AND SPECIFIC OUTCOMES}

The specific outcomes (SO) of the Life Skills programme are presented below.

\section{S01: Locality of control}

Determine the effect of internal and external control in order to illustrate understanding of the role that sources of pressure can play in one's life and there influence on those different systems of which a person may form a part.

\section{SO2: Well-being}

Improve productivity by identifying those aspects that have a detrimental influence on the wellbeing of the employee in his or her totality.

\section{SO3: Problem solving}

Equip oneself with skills and knowledge to make decisions that can change certain aspects of one's life in a problem solving manner.

\section{SO4: Stress management}

Take full responsibility for one's life by identifying one's different stressors and acquire stressmanagement techniques in order to prevent burnout and depression.

\section{SO5: Balance in your life}

Organise and manage oneself effectively according to a balanced life-style to increase contentment with life. 


\section{SO6: Communication skills}

Illustrate the meaning and components of communication in order to demonstrate their importance to the employee in the workplace.

\section{SO7: Conflict management}

Demonstrate an understanding of conflict management to enhance effectiveness in the workplace.

\section{SO8: Self-assertiveness}

Identify and discuss the following types of behaviour: passive, aggressive, passive-aggressive and self-assertive, which have an influence on how one conducts oneself at work.

\section{S09: Self-image, effectiveness and success}

Illustrate the meaning of self-image in order to develop one's understanding of the role that selfimage can play in the life of the individual and its influence on the different systems of which one may form a part.

TABLE 2

LAYOUT OF THE LIFE SKILLS PROGRAMME

\begin{tabular}{|c|l|}
\hline \multicolumn{2}{|c|}{ GOAL: THE ENHANCEMENT OF KNOWLEDGE, SKILLS AND ATTITUDE } \\
\hline MODULE & THEME \\
\hline 1 & Locality of control \\
\hline 2 & Well-being \\
\hline 3 & Problem solving \\
\hline 4 & Stress management \\
\hline 5 & Balance in one's life \\
\hline 6 & Communication skills \\
\hline 7 & Conflict management \\
\hline 8 & Self-assertiveness \\
\hline 9 & Self-image, effectiveness and success \\
\hline
\end{tabular}

\section{RESEARCH METHODOLOGY}

\section{The research design}

Evaluation research is an essential part of what social workers do, even though it is too rarely undertaken (Mitchell, 2005:111). Mitchell further states that evaluation research undoubtedly occupies an invaluable place in the hierarchy of social work research. The issue has become urgent since "we are engulfed by acute social problems within the domain of the profession as well as in the wider society". It is thus indispensable for social workers to evaluate their interventions on a continuous basis to confirm that their implementation is effective and leads to change.

Bless and Higson-Smith (2000:49) refer to evaluation research as being that which happens when the usefulness of social interventions (for example, a skills training programme) is assessed. Neuman (2003:24) indicates that it answers the question "Does it work?" Evaluation research aims to test interventions to see how effective they are and, therefore, represents an important means of linking action and research in a constructive manner. Babbie (2005:360) mentions that 
evaluation research is also referred to as programme evaluation.

Fouché (2002:271) indicates that quantitative researchers consult their lists of possible designs and select one (or develop one from the models available). A quasi-experimental design with a one-group pre-test post-test experiment was implemented in this quantitative research (Struwig \& Stead, 2001:7; Fouché \& De Vos, 2002:138-145; De Vos, 2002:383). According to Bless and Higson-Smith (2000:69), this quasi-experimental design is the most common design for impact studies. Babbie (2005:360) warns that this design may possibly be affected by some factor other than the independent variable which might cause a change between the pre-test and post-test results.

A pre-test self-constructed questionnaire was administered in which the respondents' knowledge, skills and attitudes were measured. The Life Skills programme was implemented. Forty-six of the 71 respondents $(65 \%)$ completed the post-test questionnaire six months after attending the Life Skills programme.

\section{The participants}

The Life Skills programme was presented to employees of a tertiary institution in five different workshops. The workshops varied between 14-18 people per workshop. These five workshops involved altogether 71 respondents between the ages of 24 and 64 . The sample being studied thus consisted of all the employees of the tertiary institution who attended the Life Skills programme during 2004. All participants who attended the programme participated in the study; thus the population equalled the sample and no sampling technique was therefore implemented.

\section{THE MEASURING INSTRUMENT}

As it is impossible to present this 8-hour Life Skills programme on an individual basis, it was decided to present the Life Skills programme to respondents in workshops. The use of workshops was purely coincidental and convenient, as the focus was on the evaluation of the impact of the Life Skills programme on every person attending. Five workshops for the presentation of the Life Skills programme were scheduled from February to October 2004 at the tertiary institution. Employees volunteered to attend these workshops. Each workshop lasted eight hours. Bless and Higson-Smith (2000:68) indicate that in the pre-test/post-test design the author measures the dependent variable before (pre-test on the baseline) and after (post-test) the event that is expected to bring about some change. Although this approach raises some concerns (there was no comparison control group), the difference between the before and after scores may be the result of the event that occurred between the scores.

A close-ended questionnaire was compiled consisting of 20 statements. The questionnaire was developed to measure the knowledge, skills and attitudes of employees. Seven of the statements related to their knowledge concerning their well-being, seven statements to their skills in interpersonal relationships and six statements to their attitude towards the workplace. All the items of the questionnaire were learning outcomes as formulated for the modules of the Life Skills programme. As stipulated by Bender and Lombard (2004:94), the author viewed the pretest as relating to the baseline assessment at the beginning of a new set of learning activities (the Life Skills programme). Through the pre-test the author could evaluate on what level the respondents were with regard to their knowledge, skills and attitude in the workplace. This questionnaire was pilot-tested on two employees of the institution who did not plan to attend the Life Skills programme. The questionnaire was then modified in accordance with the problems encountered during its pre-test phase. Six months after the completion of the Life Skills training programme the questionnaire was sent to the participants for anonymous completion and they 
were asked to return it to the author.

Before beginning each workshop, the respondents had the opportunity to complete these groupadministered questionnaires independently while in the group, without discussing them with the other members of the group (Delport, 2002:174). The participants were asked to read the statements and indicate whether they agreed or disagreed with the statements.

\section{RESULTS}

As in the case of this study, statistical analysis was performed manually with a calculator according to the simple frequency distribution, due to the relatively small amount of data and the number of respondents (46). Of the 46 respondents, four were male and 42 were female. Thirtyfive of the respondents were Afrikaans speaking; eight English speaking and one each spoke Northern Sotho, Tswana and Zulu respectively.

\section{Age distribution}

It is interesting to note that $57 \%$ of the respondents were from the age group $40-65$, while only $43 \%$ of the respondents were from the age group 24-40. That confirms the fact that no one is too old or too young to change; as Potgieter (2005:40) states, each person has an inherent capacity and drive towards change and everyone develops throughout his or her life, and is capable of changing and growing in ways that will make life more rewarding.

\section{Marital status}

Sixty-three percent of the respondents were married, which suggests that they felt the need to improve their interpersonal skills. Potgieter (2005:168) believes that adult education and Life Skills development training could be utilised to improve the assertiveness of client systems, which will help them to resolve conflicts and improve their interpersonal communication and relationships, all of which will have an impact on role performance.

\section{Qualifications}

More than $57 \%$ of the respondents had acquired further qualifications after matric. This indicated that people, although academically qualified, felt the need for non-formal training.

TABLE 3

\section{PRE-TEST RESULTS ON KNOWLEDGE}

\begin{tabular}{|l|c|c|c|c|}
\hline \multirow{2}{*}{\multicolumn{1}{c|}{ THEME }} & \multicolumn{4}{c|}{ RESPONSES } \\
\cline { 2 - 5 } & Yes & $\mathbf{\%}$ & No & $\%$ \\
\hline Self-knowledge: (It is selfish to say no to people) & 7 & 15 & 30 & 85 \\
\hline Eating habits: (Can have an impact on work performance) & 25 & 54 & 21 & 46 \\
\hline Exercises: (I exercise at least 3 times a week) & 14 & 30 & 32 & 70 \\
\hline Alcohol and drugs: (Helps me to relax after work) & 5 & 11 & 41 & 89 \\
\hline Caffeine: (Helps me to perform better at work) & 9 & 20 & 37 & 80 \\
\hline Stress: (Is self-generated) & 25 & 54 & 21 & 46 \\
\hline Self-image: (Low self-image is at the root of some outbursts at work) & 37 & 80 & 9 & 20 \\
\hline
\end{tabular}


TABLE 4

POST-TEST RESULTS ON KNOWLEDGE AFTER SIX MONTHS

\begin{tabular}{|l|c|c|c|c|}
\hline \multicolumn{1}{|c|}{ THEME } & \multicolumn{3}{c|}{ RESPONSES } \\
\cline { 2 - 5 } & Yes & $\%$ & No & $\%$ \\
\hline Self-knowledge: (It is selfish to say no to people) & 1 & 2 & 45 & 98 \\
\hline Eating habits: (Can have an impact on work performance) & 24 & 52 & 22 & 48 \\
\hline Exercises: (I exercise at least 3 times a week) & 24 & 52 & 22 & 48 \\
\hline Alcohol and drugs: (Helps me to relax after work) & 4 & 9 & 42 & 91 \\
\hline Caffeine: (Helps me to perform better at work) & 4 & 9 & 42 & 91 \\
\hline Stress: (Is self-generated) & 28 & 61 & 18 & 39 \\
\hline Self-image: (Low self-image is at the root of some outbursts at work) & 34 & 74 & 12 & 26 \\
\hline
\end{tabular}

TABLE 5

INCREASE/DECREASE IN KNOWLEDGE AFTER SIX MONTHS

\begin{tabular}{|l|c|c|}
\hline \multirow{2}{*}{ THEME } & \multicolumn{2}{c|}{ RESPONSES } \\
\cline { 2 - 3 } & $\begin{array}{c}\text { Increase } \\
\text { by \% }\end{array}$ & $\begin{array}{c}\text { Decrease } \\
\text { by \% }\end{array}$ \\
\hline Self-knowledge: (It is selfish to say no to people) & 13 & - \\
\hline Eating habits: (Can have an impact on work performance) & - & 2 \\
\hline Exercises: (I exercise at least 3 times a week) & 22 & - \\
\hline Alcohol and drugs: (Helps me to relax after work) & 2 & - \\
\hline Caffeine: (Helps me to perform better at work) & 11 & - \\
\hline Stress: (Is self-generated) & 7 & - \\
\hline Self-image: (Low self-image is at the root of some outbursts at work) & - & 6 \\
\hline
\end{tabular}

After six months, the total increase of knowledge was evident in five of the seven indicators. The greatest improvement (22\%) was on the importance of exercising as part of a healthy lifestyle. The total growth concerning the respondents' knowledge was 57\%. Nelson-Jones (1993:10) states that, through Life Skills training, employees gain knowledge to enable them to make the right choices. The knowledge acquired must be applied to practical situations in the workplace and in their personal lives. The author believes awareness alone does not always bring about change in behaviour, but the knowledge needs to be utilised and put into practice to bring about changes in his/her life. The skills must thus be internalised, assimilated and used. Knowledge is, therefore, the "how to do" dimension of Life Skills. 
TABLE 6

PRE-TEST RESULTS ON SKILLS

\begin{tabular}{|l|l|l|l|l|}
\hline \multirow{2}{*}{\multicolumn{1}{c|}{ THEME }} & \multicolumn{4}{c|}{ RESPONSES } \\
\cline { 2 - 6 } & Yes & \% & No & \% \\
\hline Reactions at work: (Depends on what I tell myself) & 37 & 80 & 9 & 20 \\
\hline Problem solving: (Get all worked up during problem solving) & 13 & 28 & 33 & 72 \\
\hline Stress: (Due to past experiences and can do nothing about it) & 7 & 15 & 39 & 85 \\
\hline Stress at work: (Not all can be managed) & 31 & 67 & 15 & 33 \\
\hline Communication skills: (Keep quiet most of the time) & 15 & 33 & 31 & 67 \\
\hline Conflict: (Motivates and cultivates productivity) & 37 & 80 & 9 & 20 \\
\hline Self-assertiveness: (Avoids emotional outbursts at work) & 33 & 73 & 13 & 28 \\
\hline
\end{tabular}

TABLE 7

POST-TEST RESULTS ON SKILLS AFTER SIX MONTHS

\begin{tabular}{|l|c|c|c|c|}
\hline \multirow{2}{*}{\multicolumn{1}{c|}{ THEME }} & \multicolumn{3}{c|}{ RESPONSES } \\
\cline { 2 - 5 } \multicolumn{1}{c|}{} & Yes & $\mathbf{\%}$ & No & $\mathbf{\%}$ \\
\hline Reactions at work: (Depends on what I tell myself) & 39 & 85 & 7 & 15 \\
\hline Problem solving: (Get all worked up during problem solving) & 6 & 13 & 40 & 87 \\
\hline Stress: (Due to past experiences and can do nothing about it) & 1 & 2 & 45 & 98 \\
\hline Stress at work: (Not all can be managed) & 20 & 43 & 26 & 57 \\
\hline Communication skills: (Keep quiet most of the time) & 16 & 35 & 30 & 65 \\
\hline Conflict: (Motivates and cultivates productivity) & 39 & 85 & 7 & 15 \\
\hline Self-assertiveness: (Avoids emotional outbursts at work) & 34 & 74 & 12 & 26 \\
\hline
\end{tabular}

TABLE 8: INCREASE/DECREASE OF SKILLS AFTER SIX MONTHS

\begin{tabular}{|l|c|c|}
\hline \multirow{2}{*}{\multicolumn{1}{c|}{ THEME }} & \multicolumn{2}{c|}{ RESPONSES } \\
\cline { 2 - 3 } & $\begin{array}{c}\text { Increase } \\
\text { by \% }\end{array}$ & $\begin{array}{c}\text { Decrease } \\
\text { by \% }\end{array}$ \\
\hline Reactions at work: (Depends on what I tell myself) & 2 & - \\
\hline Problem solving: (Get all worked up during problem solving) & 15 & - \\
\hline Stress: (Due to past experiences and can do nothing about it) & 13 & - \\
\hline Stress at work: (Not all can be managed) & 24 & - \\
\hline Communication skills: (Keep quiet most of the time) & - & 2 \\
\hline Conflict: (Motivates and cultivates productivity) & 5 & - \\
\hline Self-assertiveness: (Avoids emotional outbursts at work) & 2 & - \\
\hline
\end{tabular}

All the aspects related to skills improved, except for their view that to remain quiet is good communication practice. A major increase in the ability to manage stress took place after six 
months. Problem solving also showed significant improvement. The total growth concerning the respondents' skills was 61\%. Nelson-Jones (1993:10) states that the skills dimension of Life Skills entails the application of knowledge to practice. It is the translating of "knowing how to do it" into "actually doing" what is expected in a supportive environment that encourages and supports change.

TABLE 9

PRE-TEST RESULTS ON ATTITUDE

\begin{tabular}{|l|c|c|c|c|}
\hline \multicolumn{1}{|c|}{ THEME } & \multicolumn{3}{c|}{ RESPONSES } \\
\cline { 2 - 5 } & Yes & $\%$ & No & $\%$ \\
\hline $\begin{array}{l}\text { Motivation and sense of accomplishment at work: (Derived from } \\
\text { rewards and recognition) }\end{array}$ & 18 & 39 & 28 & 61 \\
\hline $\begin{array}{l}\text { Responsibility: (Feel responsible for everything going on in my } \\
\text { department) }\end{array}$ & 21 & 46 & 25 & 54 \\
\hline Quality of work performance: (Influenced by the choices I make) & 38 & 83 & 8 & 17 \\
\hline Purpose: (I identify priorities) & 39 & 85 & 7 & 15 \\
\hline Self-assertiveness: (Improves decision-making) & 43 & 93 & 3 & 7 \\
\hline Intercultural effectiveness: (Ability to adapt) & 43 & 93 & 3 & 7 \\
\hline
\end{tabular}

TABLE 10

POST-TEST RESULTS ON ATTITUDE AFTER SIX MONTHS

\begin{tabular}{|l|c|c|c|c|}
\hline \multicolumn{1}{|c|}{ THEME } & \multicolumn{3}{c|}{ RESPONSES } \\
\cline { 2 - 5 } & Yes & $\%$ & No & $\%$ \\
\hline $\begin{array}{l}\text { Motivation and sense of accomplishment at work: (Derived from } \\
\text { rewards and recognition) }\end{array}$ & 12 & 26 & 34 & 74 \\
\hline $\begin{array}{l}\text { Responsibility: (Feel responsible for everything going on in my } \\
\text { department) }\end{array}$ & 5 & 11 & 41 & 89 \\
\hline Quality of work performance: (Influenced by the choices I make) & 38 & 83 & 8 & 17 \\
\hline Purpose: (I identify priorities) & 44 & 96 & 2 & 4 \\
\hline Self-assertiveness: (Improves decision-making) & 37 & 80 & 9 & 20 \\
\hline Intercultural effectiveness: (Ability to adapt) & 44 & 96 & 2 & 4 \\
\hline
\end{tabular}


TABLE 11

INCREASE/DECREASE OF ATTITUDE AFTER SIX MONTHS

\begin{tabular}{|l|c|c|}
\hline \multicolumn{1}{|c|}{ THEME } & \multicolumn{2}{c|}{ RESPONSES } \\
\cline { 2 - 3 } & $\begin{array}{c}\text { Increase } \\
\text { by \% }\end{array}$ & $\begin{array}{c}\text { Decrease } \\
\text { by \% }\end{array}$ \\
\hline $\begin{array}{l}\text { Motivation and sense of accomplishment at work: (Derived from } \\
\text { rewards and recognition) }\end{array}$ & 13 & - \\
\hline $\begin{array}{l}\text { Responsibility: (Feel responsible for everything going on in my } \\
\text { department) }\end{array}$ & 35 & - \\
\hline Quality of work performance: (Influenced by the choices I make) & \multicolumn{2}{|c|}{ Stayed the same } \\
\hline Purpose: (I identify priorities) & 11 & - \\
\hline Self-assertiveness: (Improves decision making) & \multicolumn{2}{|c|}{13} \\
\hline Intercultural effectiveness: (Ability to adapt) & 3 & - \\
\hline
\end{tabular}

Four of the aspects concerning the respondents' attitudes showed improvement. There was no change in their views concerning their work performance, as a high percentage was already maintained. Their attitude concerning decision-making declined rather excessively and cannot be explained at this stage. An attitude improvement of $62 \%$ was observed amongst the respondents. Nelson-Jones (1993:10) states that an appropriate attitude to Life Skills is that an employee must assume personal responsibility for acquiring, maintaining, using and developing the skills. The employee must be motivated to "want to do it". The author believes that the success of an attitude change lies in the assumption that employees must want to acquire Life Skills and practise to maintain those skills. This will enhance their well-being and social functioning.

The study was undertaken to evaluate the impact of the Life Skills programme on the knowledge, skills and attitude of employees in the workplace. The findings of the study indicated improvement in the pre-test post-test questionnaire scores. Weisen and Orlley (in Maree \& Ebersohn, 2002:82) state that Life Skills are "abilities for adaptive and positive behaviour that enable individuals to deal efficiently with the demands and challenges of everyday life". NelsonJones (1993:26) emphasises that, through the provision of Life Skills, personal excellence could be achieved. This means a high level of competence, psychological wellness, self-actualisation and assuming personal responsibility. The Life Skills programme thus had a statistically high significant effect on the knowledge, skills and attitude development of employees in the tertiary institution. Caution should, however, be exercised in generalising the findings to a wider population, as there was no control or comparison group against which to judge the impact of the programme.

\section{CONCLUSIONS}

There is a need to include Life Skills acquisition in all adult training because Life Skills training can enhance adults' social functioning irrespective of age, gender, marital status or qualification. Mentally healthy and balanced employees display enhanced work performance. It is with great caution that the author suggests that a Life Skills programme could prepare employees for life at a physical, emotional, cognitive and social level. 


\section{RECOMMENDATIONS}

It is recommended that, when a Life Skills programme is presented, evaluation should be included to ensure that the programme continues to be effective. Feedback from Heads of Department/managers/supervisors on the behaviour of the respondents could be beneficial in providing further information on the effectiveness of the Life Skills programme. The ethical issue of confidentiality should, however, first be discussed with those attending the programme.

Participation in the Life Skills programme needs to remain voluntary. The focus can be shifted from a "problem"-orientated view of intervention towards a proactive investment in the workforce, focusing on strengths, competencies and development. If departments or units in the workplace can focus on the attendance of the employees as a team, teamwork can be enhanced, as specific development areas indicated by the team, can be addressed.

\section{REFERENCES}

BABBIE, E. 2005. The basics of social research $\left(3^{\text {rd }}\right.$ ed). United States: Thomson, Wadsworth.

BENDER, C.J.G. \& LOMBARD, A. 2004. Personal and International effects of a life skills programme on grade 7 leaners. Social Work/Maatskaplike Werk, 40(1):87-106.

BLESS, C. \& HIGSON-SMITH, C. 2000. Fundamentals of social research methods. An African perspective. Cape Town: JUTA.

CARRELL, M.R., ELBERT, N.F. \& HATFIELD, R.D. 1995. Human resource management global strategies for managing a diverse workforce $\left(5^{\text {th }}\right.$ ed $)$. New Jersey: Simon \& Schuster Company.

DELPORT, C.S.L. 2002. Quantitative data collection methods. In: DE VOS, A.S. (ed), STRYDOM, H., FOUCHÉ, C.B. \& DELPORT, C.S.L. 2002. Research at grass roots. For the social sciences and human service professions $\left(2^{\text {nd }}\right.$ ed). Pretoria: Van Schaik Publishers.

DE VOS, A.S. 2002. Programme evaluation. In: DE VOS, A.S. (ed), STRYDOM, H., FOUCHÉ, C.B. \& DELPORT, C.S.L. Research at grass roots. For the social sciences and human service professions $\left(2^{\text {nd }}\right.$ ed). Pretoria: Van Schaik Publishers.

DE VOS, A.S., FOUCHÉ, C.B., \& VENTER, L. 2002. Quantitative data analysis and interpretation. In: DE VOS, A.S. (ed), STRYDOM, H., FOUCHÉ, C.B. \& DELPORT, C.S.L. Research at grass roots. For the social sciences and human service professions $\left(2^{\text {nd }}\right.$ ed). Pretoria: Van Schaik Publishers.

FOUCHÉ, C.B. \& DE VOS, A.S. 2002. Quantitative research designs. In: DE VOS, A.S. (ed), STRYDOM, H., FOUCHÉ, C.B. \& DELPORT, C.S.L. Research at grass roots. For the social sciences and human service professions $\left(2^{\text {nd }}\right.$ ed). Pretoria: Van Schaik Publishers.

FOUCHÉ, C.B. 2002. Research strategies. In: DE VOS, A.S. (ed), STRYDOM, H., FOUCHÉ, C.B. \& DELPORT, C.S.L. Research at grassroots. For the social sciences and human service professions $\left(2^{\text {nd }}\right.$ ed). Pretoria: Van Schaik Publishers.

MAGNEY, J. 1996. Teamwork and the need for cooperative learning. Labour Law Journal, 564-570.

MAREE, J.G. \& EBERSOHN. L. 2002. Life skills and career counselling. Sandown: Heinemann Publishers.

MESSMER, M. 2001. Interpersonal skills: The new essential in accounting. The National Public Accountant, 44(1):28-29. 
MITCHELL, W.A. 2005. The value of evaluation. Die Maatskaplikewerk NavorserPraktisyn/The Social Work Practitioner-Researcher, 17(2).

NELSON- JONES, R.V. 1993. Life skills helping: Helping others through a people-centered approach. California: Brooks Cole Publishing.

NEUMAN, W.L. 2003. Social research methods. Qualitative and quantitative approaches $\left(5^{\text {th }}\right.$ ed). USA: Pearson Education, Inc.

ROUP, D. 1994. People dynamics.

POTGIETER, M.C. 2005. The social work process. Reproduced by content solutions. Pretoria: Content Solutions.

SLOAN, R.P., GRUMAN, J.C. \& ALLERGRANTE, J.P. 1987. Investing in employee health. San Francisco: Jossey Bass.

STRUWIG, F.W. \& STEAD, G.B. 2001. Planning, designing and reporting research. South Africa: Pearson Education.

TAUTE, F.M. 1992. Die ontwikkeling en evaluering van 'n lewensverrykingsopvolgprogram. Johannesburg: Randse Afrikaanse Universiteit. (DLitt et Phil Thesis)

TSCHOHL, J. 2004. Geeks: Train and handle with care! The Canadian Manager, 29(3):24.

\section{ACKNOWLEDGEMENT}

The author would like to acknowledge the contributions of Rina Buys, Viwe Dunjwa and Gayle Schmidt to this article.

Dr Florinda Taute, Lecturer, Department of Social Work and Criminology, University of Pretoria, Pretoria, South Africa. 